На протяжении 60 лет бренд Dove помогает всем девушкам почувствовать свою красоту и индивидуальность. В настоящее время компания распространяет хештег \#МояКрасотаМоиПравила и старается держать за собой заданную планку. Под этим хештегом было запущено множество видео роликов как в интернете, так и на ТВ. Героини роликов - самые обычные девушки. Однако в них присутствует огромная сила, они обладают особым видением своей красоты, а также не стесняясь рассказывают свои истории. По данным опроса, около $62 \%$ женщин хотели бы видеть в рекламе настоящую красоту, ту, что дала природа. Компания Dove призывает именно к этому, показывая пример собой.

Проанализировав все социальные кампании бренда, можно сделать вывод, что главная цель Dove - разрушение прочных стереотипов, которые сложились в обществе. Очень важно отметить грамотность выстроенной рекламной кампании для девочек и их мам. По моему мнению, это очень интересный стратегический ход: таким образом, бренд одной рекламой охватывает огромную аудиторию. Приглашенные психологи для девочек от компании Dove говорит о том, что бренд не просто выпускают ролики, чтобы повысить свой имидж, они заботятся о подрастающем поколении.

Идея принимать себя настоящей, неидеальной идет наряду с проблемой принятия других. Если проблему, которая стоит в корне устранить, то все вопросы, которые сопрягаются с ней, исчезнут: жестокое обращение подростков со сверстниками, психологическое насилие в школах и интернатах, уменьшится процент детского суицида. Компания понимает, что непринятие себя или других из-за внешних особенностей, влечет за собой массу других последствий. Социальную рекламу Dove относят к лучшим рекламным проектам XXI века.

В настоящее время все крупные бренды занимаются разработкой общественных проектов. Социальная реклама начала играть роль своеобразного симбиоза коммерческого маркетинга с социальным оттенком. Это происходит, потому что некоторые компании создают социальную рекламу с целью привлечь внимание к бренду, эмоционально привязывать его к потребителю.

$$
* * *
$$

1. Албенова по И.Ф. по Социальные по технологии: по теория по и по практика по// по Социальная по работа: по история по теории по и по технологии: по сб. по науч. по тр. по Ярославль: по Диа-Пресс, по 2017.- С. по 93 no - no 103.

2. Веселов, по С. по Оценка по эффективности по рекламной по деятельности по о // по Рекламные по технологии. № - -- 2015. no - no № 5. no - no С. no 2 no - no 4.

3. Волошин, по П. по Сети по социальной по рекламы no no // no Рекламный по мир. по -2018.-№ 4.- С. по $10-12$.

4. Еляков поА.Д. $\mathrm{n}$ Современная по информационная по революция по // по Социологические по исследования. no - 2011. no - №10. no - C. no 29 no - no 38.

5. Уэллс, nо У. nо Реклама: по принципы по и по практика по . - по СПб.: по Питер, nо 2016. no - no 735 nо с.

6. Николайшвили Г.Г. Социальная реклама: теория и практика. М.: АСПЕКТ ПРЕСС, 2008 [Электронный pecypc] URL: https://www.studmed.ru/nikolayshvili-g-g-socialnaya-reklama-teoriya-i-praktika_e309be9ae23.html (дата обращения:10.08.2021)

7. Проект Dove по повышению самооценки [Электронный ресурc] URL: https://www.dove.com/ru/home.html (дата обращения:10.08.2021)

\title{
Пронина А.Н. \\ Изучение внешних и внутренних мотивов учебной деятельности современных старшеклассников
}

Елецикий государственный университет им. И.А. Бунина

(Россия, Елеи)

doi: 10.18411/trnio-09-2021-72

\section{Аннотация}

Внешние и внутренние мотивы учебной деятельности старшеклассников являются структурным компонентом данной деятельности и обеспечивают её эффективность. 
Внешние мотивы учебной деятельности современных старшеклассников включают мотивы самоутверждения и мотивации достижения успеха, которые характеризуются средним уровнем. Внутренние мотивы учебной деятельности современных старшеклассников включают мотивы направленности на получение знаний и реализацию познавательных потребностей, которые характеризуются средним уровнем сформированности.

Ключевые слова: внешние мотивы учебной деятельности, внутренние мотивы учебной деятельности, современные старшеклассники.

\section{Abstract}

The external and internal motives of the educational activity of high school students are a structural component of this activity and ensure its effectiveness. The external motives of the educational activity of modern high school students include the motives of self-affirmation and motivation to achieve success, which are characterized by an average level. The internal motives of the educational activity of modern high school students include the motives of orientation to the acquisition of knowledge and the realization of educational needs, which are characterized by an average level of formation.

Keywords: external motives of educational activity, internal motives of educational activity, modern high school students.

Учебная деятельность побуждается различными мотивами, как внешними, так и внутренними мотивами. Отечественными исследователями (Гордеева Т.О., Гижицкий В.В. [1] Карпова Е.В. [2] Мильман В.Э. [3]) изучена и описана внешняя структура, предметное содержание учебной деятельности, разработаны её основные характеристики.

Учебная деятельность оказывает значительное влияние на становление личности старшеклассника, поскольку является способом реализации, поддержания и развития Я. Вместе с тем учебная деятельность способствует самоопределению и профессиональной ориентации личности старшеклассника, при этом между интересами к учебному предмету и будущей профессии устанавливается тесная связь. С одной стороны перспективы привлекательной будущей профессии стимулирует учебные интересы, с другой - учебные интересы позволяют повышать качество усвоения и изучения учебных предметов.

Цель исследования: исследовать внутренние и внешние мотивы учебной деятельности современных старшеклассников.

Характеристика выборки. Генеральная совокупность испытуемых составила 150 школьников из 4- х 10 классов МБОУ «Гимназия №11» г. Ельца и МБОУ школа №1 г. Ельца. Средний возраст участников составил 16.2 лет.

Для оценки внешних мотивов учебной деятельности у старшеклассников, таких как мотив самоутверждения, мотив достижения нами были отобраны следующие методики: методика «Стратегии самоутверждения личности» (Е.П. Никитин, Н.Е. Харламенкова), опросник Т. Элерса для изучения мотивации достижения успеха.

По методике «Стратегии самоутверждения личности» (Е.П. Никитин, Н.Е. Харламенкова) выявлено, что у 58\% старшеклассников более высокие показатели по шкале «конструктивное самоутверждение» (КС) свидетельствуют о том, что у испытуемого преобладает конструктивное самоутверждение, следовательно, ему свойственны эмоциональная устойчивость, самостоятельность и компетентность в общении, проявление к другим уважения, интереса, симпатии, принятие, а также ожидание положительного отношения к своей личности со стороны других людей. У $32 \%$ старшеклассников более высокие показатели по шкале «деструктивное самоутверждение» (ДС) свидетельствуют о том, что у испытуемого преобладает деструктивный тип самоутверждения, который характеризуется импульсивностью, негативизмом, агрессией, отрицанием личностной ценности и значимости других людей, бестактностью, эмоциональной несдержанностью. Для таких обучающизся старших классов зафиксирован неадекватный (завышенный или 
заниженный) уровень самоуважения, ожидание отрицательного отношения к себе со стороны других людей.

У $10 \%$ старшеклассников более высокие показатели по шкале «отказ от самоутверждения» (ОС) свидетельствуют о преобладании отказа от самоутверждения, наличием депрессии, аутоагрессией, отказом от самореализации и саморазвития, низкий уровень достижений, самоуничижение, самоотрицание, пассивно-безразличное поведение. Такие старшеклассники не видят чётких перспектив своего обучения в школе.

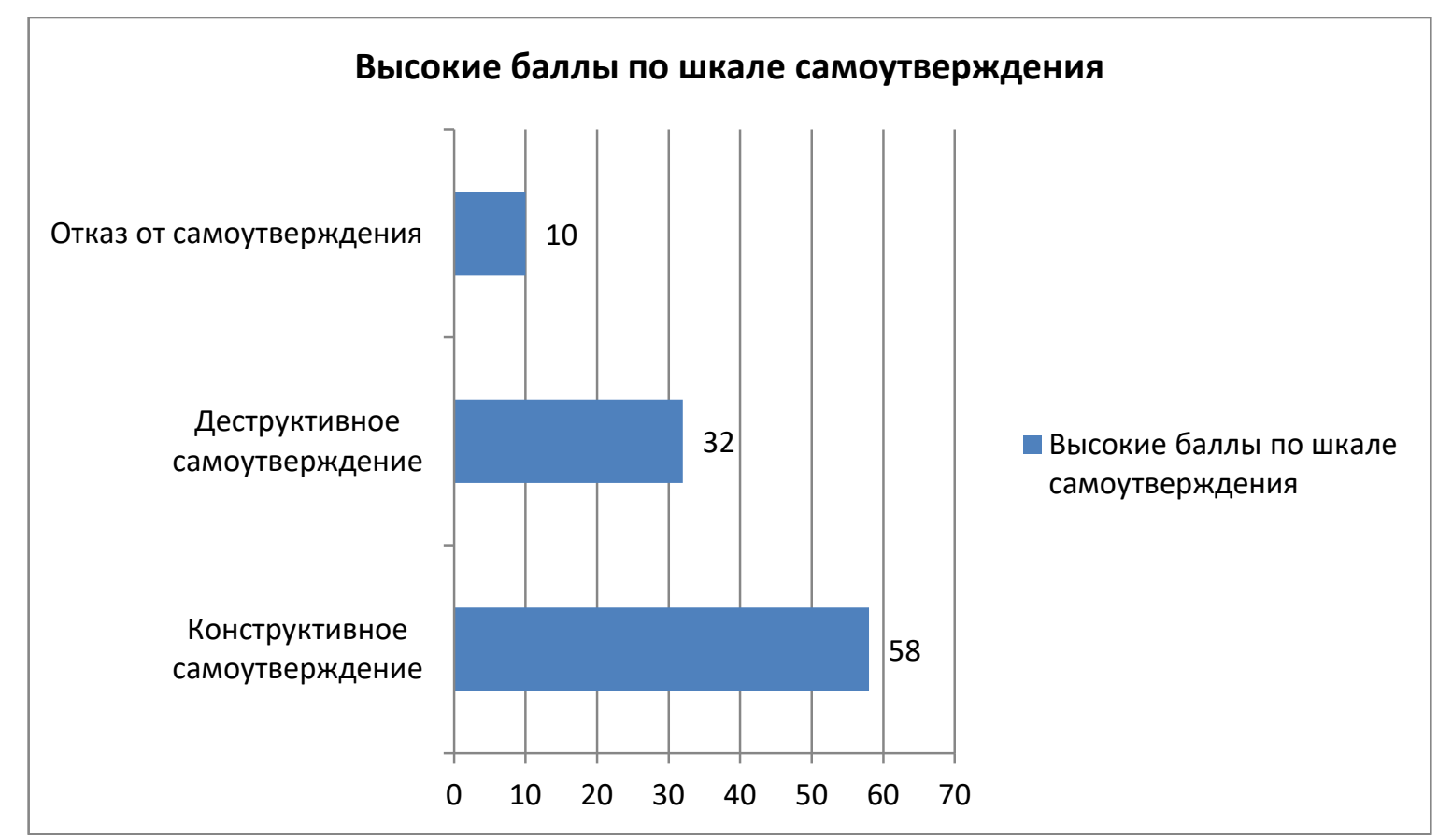

Рисунок 1. Диаграмма процентного соотношения по шкалам самоутверждения старшеклассников (\%)

Представим результаты теста Т. Элерса по изучению мотивации достижения успеха (рис.2).

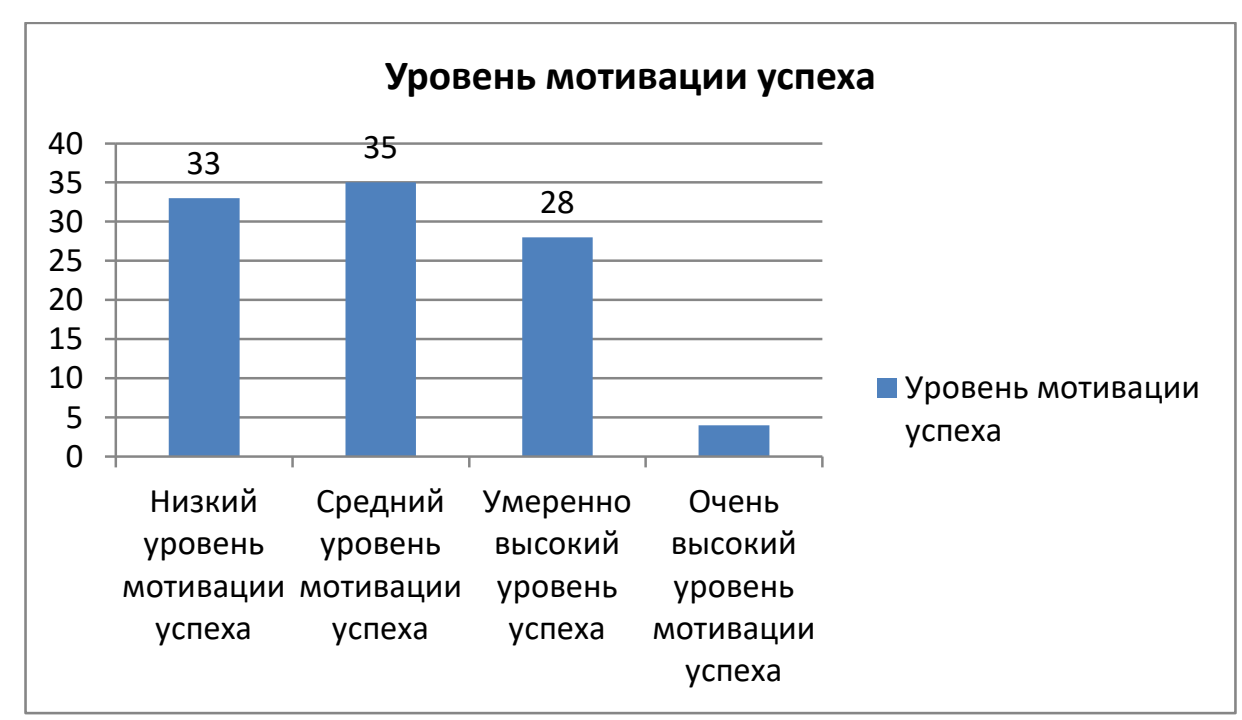

Рисунок 2. Диаграмма процентного соотношения уровней мотиваџии успеха у старшеклассников (\%)

Нами выявлено, что старшекласники с умеренным уровнем успеха (35\%) не предпочитают рисковать, поэтому в учебной деятельности стараются не выполнять трудные учебные задания, чтобы не разочароваться в результатах. Старшеклассники с низким уровнем мотивации успеха (33\%) также бояться потерпеть неудачи в учебной деятельности. 
Старшеклассники с высоким уровнем мотивации успеха (28\%) не боятся рисковать и выполняют в учебной деятельности более сложные задания.

Для исследования внутренних мотивов учебной деятельности нами применялась следующие методики: методика "Направленность на приобретение знаний" (Е.П. Ильин, Н.А. Курдюкова).

Представим результаты методики "Направленность на приобретение знаний" (Е.П. Ильин, Н.А. Курдюкова) (рис.3).

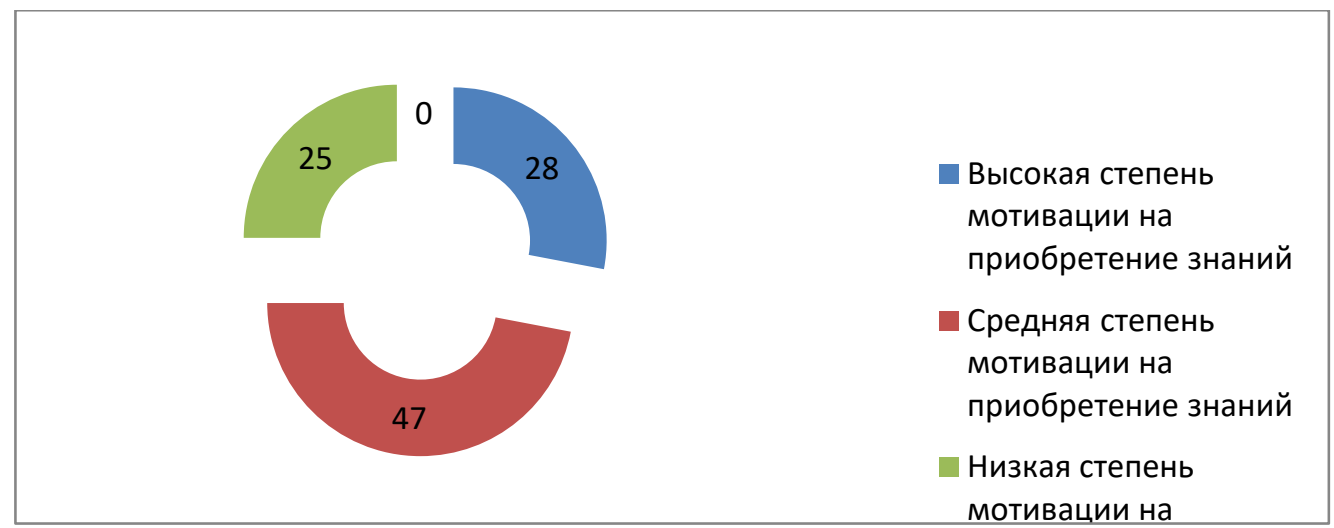

Рисунок 3. Степень выраженности мотивации на приобретение знаний у старшеклассников по результатам методики "Направленность на приобретение знаний" (Е.П. Ильин, Н.А. Курдюкова) (\%)

У большинства современных старшеклассников (28\%) выявлена высокая степень мотивации на приобретение знаний, что свидетельствует о направленности мотивов учебной деятельности на её предмет, т.е. на результат - освоение и получение знаний. У 47\% современных старшеклассников умененная степень мотивации на приобретение знаний, что свидетельствует о том, что данная мотивация неустойчива в различных учебных ситуациях, может меняться как в сторону положительную, так и отрицательную сторону и зависит от многих факторов. Но вместе с тем можно её характеризовать как положительную стабильную.

У 25\% современных старшеклассников низкая степень мотивации на приобретение знаний, которая является отрицательной и не позволяет получать высокие результаты и вызывает отрицательное отношение к учебной деятельности.

Применение методики «Стратегии самоутверждения личности» (Е.П. Никитин, Н.Е. Харламенкова) показало, что половина исптыуемых современных старшеклассников имеют более высокие показатели конструктивного самоутверждения, что очень значимо в учебной деятельности.

Опросник Т. Элерса для изучения мотивации достижения успеха выявил, что старшекласники с умеренным уровнем успеха не предпочитают рисковать, поэтому в учебной деятельности стараются не выполнять трудные учебные задания, чтобы не разочароваться в результатах.

У большинства современных старшеклассников выявлена высокая степень мотивации на приобретение знаний, что свидетельствует о направленности мотивов учебной деятельности на её предмет, т.е. на результат - освоение и получение знаний.

$$
* * *
$$

1. Гордеева Т.О., Гижицкий В.В. Универсальность и специфичность внутренней и внешней мотивации учебной деятельности и их роли как предикторов академических достижений //Известия дагестанского государственного педагогического университета. Психолого-педагогические науки, 2013.№ 3 (24). С. 8-17.

2. Карпова Е.В. Структура и генезис мотивационной сферы личности в учебной деятельности: автореф. дис. ... д-ра психол. наук / Е.В. Карпова; Ярославский государственный педагогический университет им. К.Д. Ушинского. Ярославль, 2009.

3. Мильман В.Э. Внутренняя и внешняя мотивация учебной деятельности / В.Э. Мильман // Вопросы психологии. 1987. №5. С. 129-138. 